\title{
Review
}

\section{The neoliberal subject: Resilience, adaptation and vulnerability}

\author{
David Chandler and Julian Reid \\ Rowman \& Littlefield, Lanham, 2016, x + 204 pp., \\ ISBN: 978-1-7834-8771-4
}

Contemporary Political Theory (2018) 17, S78-S81. https://doi.org/10.1057/s41296017-0122-2; published online 27 June 2017

The ubiquity of neoliberalism as a category used by the left to understand contemporary economic and political reality is without question. But the contours of neoliberalism are not always clear, nor are the subjects who live within it. David Chandler and Julian Reid bring us a volume which is the first study of the implications of neoliberal discourses of resilience for theories and practices of human subjectivity' (p. 1). The book offers a theoretical discussion between two thinkers, who, while fundamentally agreeing on the core problematic of neoliberal subjectivity over the last two decades, hold different visions of how we might go about transforming both our neoliberal world and the subjects within it. They both ultimately agree that from neoliberalism emerges a degraded subject, one whose skills of resilience and adaptability may be enhanced, but whose autonomy and agency as an individual are fundamentally impoverished. While the promised dialogical nature of this theoretical encounter never directly manifests in this text, if we treat each author's set of essays separately there is much that illuminates how subjects are perceived through the eyes of policy, economics and international relations discourse in the contemporary world.

David Chandler's approach to neoliberalism addresses the relationship between the nature of liberal and neoliberal subjects, and his essays are critical readings of key economic texts and policy documents. A key theme throughout is the neoliberal exacerbation of methodological individualism. For example, when looking at resilience Chandler focuses on the 'socialization of security', whereby the responsibility of identifying and solving social problems is displaced from the state to the individual. He locates this tendency in new institutional economics and in the work of Friedrich Hayek, which both predictably offer a less than robust understanding of human subjectivity. Chandler further argues that Anthony Giddens' Beyond Left and Right (1994) and The Third Way (1998) demonstrate the shift from the external to the internal world, as 'the transformative activity of the autotelic self is focused upon the internal realm' (p. 45).

(c) 2017 Macmillan Publishers Ltd. 1470-8914 Contemporary Political Theory Vol. 17, S2, S78-S81 
The social contradiction presented by the return to the individual reveals itself in Chandler's essay on adaptation, where he addresses 'adaptive capacities' in development discourse, both in policy and in the work of proponents such as Amartya Sen and Martha Nussbaum. The shift from state responsibility to the internalization of responsibility in the individual subject (p. 93) is effected by a move away from the classical liberal value of 'the freedom to choose' - which assumes that freedom is essential to autonomy - to the neoliberal 'capability to choose' - which sees freedom as the continuous empowerment of the disenfranchised through capacity building. There is, he argues, an inherent infantilization of the postcolonial subject in this way of thinking, as it assumes that if these subjects were to make better choices they would be more resilient to the challenges presented by the world. In a like vein, Chandler's final essay on vulnerability delves into new institutionalist thinking (represented here by Douglass North) and shows that the problematic of neoliberalism is how individuals and communities can overcome vulnerabilities and learn to process information to become self-aware and to govern themselves more reflexively' (p. 123). Thus, vulnerable subjects are placed at the heart of social explanation and become the perceived cause of social problems instead of market forces or structural relations.

Ultimately, Chandler wishes to 'suggest ways in which we can begin to reinstate the human subject through bringing back the external world as an object of engagement and transformation' (p. 142). These suggestions presuppose a return to the notion of the universal subject of liberalism, which allowed for a certain subjective equality and autonomy as guiding principles in discussions of political and economic change. One might question how universal these principles have ever been, or how many subjects they would have included within their very specific epistemological and cultural parameters. Yet the point of Chandler's critique is clear: we will not change structural injustice by forcing the subject of inequality to simply change their capacity to be resilient, to adapt and to overcome the epistemological causes of their vulnerability.

Julian Reid begins, as Chandler does, by thinking the neoliberal through the lens of the liberal, but instead uses the Foucauldian framework of biopolitics and its focus on the valorization of life to show how liberalism and neoliberalism are inherently security projects. Because Reid believes these security projects to be limited in their conception of subjectivity, and limiting of the subjects they describe, he focuses throughout his essays on alternatives to neoliberal subjectivity. For Reid, the imagination is one of the most emancipatory subjective faculties. In his first essay, he reveals the power of imaginative action in contrast to the reactionary struggle of neoliberal subjects: '.. imaginative action is what enables human beings to forsake the current courses of their worlds in constitution of new ones through, not the transformation of themselves, but the exercise of agency on their worlds, through the rendering of the image upon it' (p. 19). Reid calls for a renovation of the subject. He postulates the existence of a psychopolitical subject

(c) 2017 Macmillan Publishers Ltd. 1470-8914 Contemporary Political Theory Vol. 17, S2, S78-S81 S79 
who is inherently hostile to the terms of liberal and neoliberal biosubjectivity and inclined towards imaginative action.

Reid's approach relies on an archaeology of the biologized subject. He looks at the marriage between the biological sciences and liberal philosophy and shows how a biological conception of the subject and its place in the world actually disenfranchises the subject. This is particularly salient in recent sustainable development discourse where the concern for the sustainability of the biosphere becomes a prescription for neoliberal economistic subjectivity. For Reid, this discourse employs a double movement. First, theories of survival and protection which apply to the biosphere are transposed onto the human, who must be resilient much like the rest of the organic world. Next, the human subject must internalize the logic of neoliberal survival and adapt their practices in their farming techniques, extraction patterns and modes of production. These subjects are often the global poor, Reid reminds us, and the sustainable development doctrine which they internalize is precisely that which continues to play to the logic of global capital. Further yet, it is their lack of knowledge and sustainable practices that can be blamed for causing ecological problems in the first place.

Reid observes that neoliberal adaptability and its correlate 'war on autonomy' can be traced to currents in microbiology where the 'exposure to danger is essential to living systems' (p. 102) such that the possession of 'buffer capacities' or the organism's ability to 'absorb perturbations' lends to an image of reactive being. Biological systems understand organisms to work only as part of a greater whole. Thus, in human terms, autonomy is a threat to our collective survival. Reid argues that those who are not wholly enframed by communicative connectivity (i.e. internet and social media) threaten the dominant order, whether their lack of connectivity is intentional or otherwise: 'either way disconnected and autonomous peoples must be made into connected and dependent ones' (p. 115). As a result, Reid rejects 'trope of the vulnerable subject' as part of the liberal tradition itself and instead attempts to reinvigorate a subject capable of imagining itself otherwise, heralding a renewed hubris and eschatological courage to change the conditions of the world.

While the book is intended as a set of dialogues, there are instead two monologues, two individual sets of essays on the neoliberal subject placed side by side as if in conversation. Two primary differences between the authors are discussed in the concluding interview with Gideon Baker. The first is compelling and concerns the relationship between the individual and social change. Simply put, Chandler believes that change must begin in the world, not in our heads, whereas Reid believes we must change the nature of subjectivity in order to trigger change in the world. The second difference resides in their understanding of Kantian philosophy, a theme that appears abruptly and unconvincingly in this conclusion, as neither author spends much time discussing Kant in their essays: they do not systematically address the same texts, as one might hope for in the course of a theoretical dialogue. 
While both sets of essays provide significant insight into the constitution of neoliberal subjectivity on a variety of levels, they also engage in a certain conceptual slippage from 'neoliberalism' as a subject itself, with the power to ascribe characteristics onto its subjects, to 'neoliberal policy', which is written by specific people and aims at specific subjects, to 'neoliberal thought', which might be ascribed to a variety of thinkers and policy makers. In a book that is attempting to shed light on the nature of neoliberal subjectivity, and on those who ascribe subjects this subjectivity, careful conceptual delineation is needed. In its absence, the reader is left to tarry with varying epistemological orders of critique in such a way that 'neoliberalism' itself never comes into focus. This book is at its very strongest when dealing with specific policy reports, disciplinary discourse and bodies of economic writing. It raises the question, however, of whether a universally meaningful theory of neoliberal subjectivity is possible.

Sonya Scott

York University, Toronto, ON M3J 1P3, Canada smscott@yorku.ca 